Florida International University FIU Digital Commons

FCE LTER Journal Articles

FCE LTER

2005

\title{
Experimental nutrient enrichment causes complex changes in seagrass, microalgae, and macroalgae community structure in Florida Bay
}

\author{
Anna R. Armitage \\ Department of Biological Sciences and Southeast Environmental Research Center, Florida International University, \\ armitage@fiu.edu \\ Thomas A. Frankovich \\ Department of Biological Sciences and Southeast Environmental Research Center, Florida International University, \\ tfrankov@fiu.edu \\ Kenneth L. Heck Jr. \\ Dauphin Island Sea Laboratory \\ James W. Fourqurean \\ Department of Biological Sciences and Southeast Environmental Research Center, Florida International University, \\ fourqure@fiu.edu
}

Follow this and additional works at: https://digitalcommons.fiu.edu/fce_lter_journal_articles

\section{Recommended Citation}

Armitage, A.R., J.W. Fourqurean. 2009. Stable isotopes reveal complex changes in trophic relationships following nutrient addition in a coastal marine ecosystem. Estuaries and Coasts 32: 1152-1164.

This material is based upon work supported by the National Science Foundation through the Florida Coastal Everglades Long-Term Ecological Research program under Cooperative Agreements \#DBI-0620409 and \#DEB-9910514. Any opinions, findings, conclusions, or recommendations expressed in the material are those of the author(s) and do not necessarily reflect the views of the National Science Foundation. This work is brought to you for free and open access by the FCE LTER at FIU Digital Commons. It has been accepted for inclusion in FCE LTER Journal Articles by an authorized administrator of FIU Digital Commons. For more information, please contact dcc@fiu.edu, jkrefft@fiu.edu. 
Armitage et al.

1

Complex nutrient effects on seagrass, algae

1 In press at Estuaries

2

3 Experimental nutrient enrichment causes complex changes in seagrass, microalgae, and

4 macroalgae community structure in Florida Bay

5

6

$7 \quad$ Anna R. Armitage ${ }^{1}$

8 Department of Biological Sciences and Southeast Environmental Research Center,

9 Florida International University, Miami, FL 33199

$10 \quad \mathrm{Ph} 305-348-7317 \quad$ Fax 305-348-4096 Email armitage@fiu.edu

11

12 Thomas A. Frankovich

13 Department of Biological Sciences and Southeast Environmental Research Center,

14 Florida International University, Miami, FL 33199

15

16 Kenneth L. Heck, Jr.

17 Dauphin Island Sea Lab, 101 Bienville Boulevard, Dauphin Island, AL 36528

18

19 James W. Fourqurean

20 Department of Biological Sciences and Southeast Environmental Research Center,

21 Florida International University, Miami, FL 33199

22

$23{ }^{1}$ Corresponding author 


\section{Abstract}

25 We examined the spatial extent of nitrogen $(\mathrm{N})$ and phosphorus $(\mathrm{P})$ limitation of each of the 26 major benthic primary producer groups in Florida Bay: seagrass, epiphytes, macroalgae, and

27 benthic microalgae, and characterized the shifts in primary producer community composition

28 following nutrient enrichment. We established 24 permanent $0.25 \mathrm{~m}^{2}$ study plots at each of six

29 sites across Florida Bay and added $\mathrm{N}$ and $\mathrm{P}$ to the sediments in a factorial design for 18 months.

30 Tissue nutrient content of the turtlegrass Thalassia testudinum revealed a spatial pattern in $\mathrm{P}$

31 limitation, from severe limitation in the eastern bay ( $\mathrm{N}: \mathrm{P}>96: 1)$, moderate limitation in two

32 intermediate sites $(\sim 63: 1)$, and balanced with $\mathrm{N}$ availability in the western bay $(\sim 31: 1)$. $\mathrm{P}$

33 addition increased $\underline{\text { T. testudinum }}$ cover by $50-75 \%$ and short-shoot productivity by up to $100 \%$,

34 but only at the severely P-limited sites. At sites with an ambient N:P ratio suggesting moderate $\mathrm{P}$

35 limitation ( 63:1), few seagrass responses to nutrients occurred. Where ambient $\underline{\text { T. testudinum }}$

36 tissue $\mathrm{N}: \mathrm{P}$ ratios indicated $\mathrm{N}$ and $\mathrm{P}$ availability was balanced $(\sim 31: 1)$, seagrass was not affected

37 by nutrient addition but was strongly influenced by disturbance (currents, erosion). Macroalgal

38 and epiphytic and benthic microalgal biomass were variable between sites and treatments. In

39 general, there was no algal overgrowth of the seagrass in enriched conditions, possibly due to the

40 strength of seasonal influences on algal biomass or regulation by grazers. $\mathrm{N}$ addition had little

41 effect on any benthic primary producers throughout the bay. Overall, the Florida Bay benthic

42 primary producer community was P-limited, but P-induced alterations of community structure

43 were not uniform among primary producers or across Florida Bay and did not always agree with

44 expected patterns of nutrient limitation based on stoichiometric predictions from field assays of

$45 \quad$ T. testudinum tissue N:P ratios. 


\section{Introduction}

Increased nutrient input as a consequence of human land use can cause changes in species composition and primary productivity in terrestrial and aquatic habitats (Borum and Sand-Jensen 1996; Smith et al. 1999; Kennish 2002). Urban and agricultural development in watersheds render coastal systems particularly susceptible to nutrient input (Nixon 1995; Smith et al. 1999), making the prediction of nutrient loading effects on coastal systems a key management goal. Nitrogen $(\mathrm{N})$ is frequently a limiting nutrient in coastal systems, but increasing evidence for phosphorus $(\mathrm{P})$ limitation suggests that both $\mathrm{N}$ and $\mathrm{P}$ enrichment are of concern in nearshore habitats (Howarth 1988).

Frequently documented responses of tropical and subtropical seagrasses to elevated $\mathrm{N}$ or $\mathrm{P}$ supply include increases in biomass and productivity (Powell et al. 1989; Tomasko and Lapointe 1991; Lee and Dunton 2000), though consequences of nutrient enrichment vary widely within and among species and regions. Seagrass beds in carbonate sediments are generally considered to be P-limited (Short et al. 1985) and may respond strongly to P enrichment, though $\mathrm{N}$-limitation in carbonate sediments has been documented as well (Udy et al. 1999; Ferdie and Fourqurean 2004). Different nutrient requirements among seagrass species can cause co-occurring species to be limited by different nutrients (Udy and Dennison 1997). Furthermore, different levels of $\mathrm{N}$ or P limitation for individual seagrass species can occur along regional nutrient availability gradients (Lee and Dunton 2000; Fourqurean and Zieman 2002; Ferdie and Fourqurean 2004).

Macroalgae are important components of seagrass communities as well, but increases in 6 nutrient supply can cause algal proliferations that overgrow and displace aquatic vegetation 7 (Duarte 1995; Valiela et al. 1997; Hauxwell et al. 2001; McGlathery 2001). Evidence for both P-

8 limitation (Lapointe 1989) and N-limitation (Larned 1998) suggests that tropical macroalgal 
69 responses to nutrient enrichment are highly species-specific and vary among regions. Like

70 seagrasses, tropical macroalgae may also exhibit intraspecific variation in responses to nutrient

71 enrichment along gradients corresponding to background nutrient influence (Fong et al. 2003).

72 However, algae do not necessarily exhibit the same limitation patterns as co-occurring seagrasses

73 (Ferdie and Fourqurean 2004).

74 Microalgae, both benthic and epiphytic, comprise another important primary producer in

75 seagrass communities (Moncreiff et al. 1992). Microalgal biomass and productivity can increase

76 when enriched with $\mathrm{N}$ or $\mathrm{P}$ (Nilsson et al. 1991) and can overgrow other aquatic vegetation

77 (Tomasko and Lapointe 1991). However, microalgal responses to nutrient enrichment may also

78 be strongly limited by biotic factors including herbivory (Williams and Ruckelshaus 1993).

79 Florida Bay is a shallow, semi-enclosed system with extensive seagrass beds dominated by

80 Thalassia testudinum (turtle grass). T. testudinum tissue in much of Florida Bay has a N:P ratio

81 of >>30:1 with a maximum of 115:1 (Fourqurean and Zieman 2002), suggesting severe P-

82 limitation (Atkinson and Smith 1983). A complex network of shallow carbonate banks within the

83 bay restricts water flow and creates numerous, effectively isolated basins, such that sites in close

84 proximity may have dramatically different stoichiometric patterns. A spatial gradient in N:P of

85 seagrass tissue (Fourqurean et al. 1992) and the water column (Fourqurean et al. 1993) suggest

86 that $\mathrm{P}$ availability is highest along the western marine boundary of the Bay and decreases

87 towards the east and north. From this pattern, it has been hypothesized that the marine waters of

88 the Gulf of Mexico are the major P source for Florida Bay (Fourqurean et al. 1992; Fourqurean

89 et al. 1993); these hypotheses have been supported with budgetary calculations (Rudnick et al.

90 1999). There is evidence, however, that $\mathrm{N}$ can limit some components of the pelagic primary

91 producers in the western regions of the Bay (Lavrentyev et al. 1998; Tomas et al. 1999), and 
92 arguments have been made that some of the changes in the Florida Bay ecosystem, including loss

93 of seagrass and increases in phytoplankton abundance, may be a result of increased N loading

94 into western Florida Bay (Brand 2002; Lapointe and Barile 2004). Given the gradient of N:P and

95 the finding of $\mathrm{N}$ limitation of benthic primary producers offshore towards the Florida Barrier

96 Reef (Ferdie and Fourqurean 2004), such arguments bear testing experimentally.

97 Our objectives were to evaluate the spatial extent of nutrient ( $\mathrm{N}$ or $\mathrm{P}$ ) limitation of each of

98 the major benthic primary producer groups in Florida Bay: seagrass, epiphytes, macroalgae, and

99 benthic microalgae, and characterize the shifts in primary producer community composition

100 following fertilization of the seagrass community. We hypothesized that $\mathrm{N}$ and $\mathrm{P}$ enrichment

101 would stimulate acute primary producer responses corresponding to the degree of nutrient

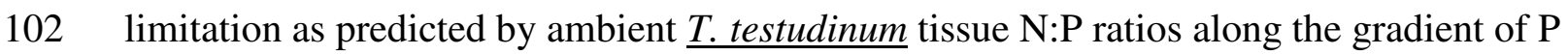

103 availability in the Bay. We also predicted that nutrient enrichment would shift primary producer

104 community composition towards micro- and macroalgal species with high turnover rates (sensu

105 Duarte 1995).

106 Methods

107 To evaluate the effects of $\mathrm{N}$ and $\mathrm{P}$ enrichment across a P-availability gradient within

108 Everglades National Park in Florida Bay, we used a three-way split-plot ANOVA design, where

109 the factors were $\mathrm{P}$ addition, $\mathrm{N}$ addition, and region of the bay. In October 2002 we established

110 six study sites (all depths $<2 \mathrm{~m}$ ), with two sites nested in each of three major regions of the bay:

111 Northeast, Interior/Central, and Gulf, as defined by Zieman et al. (1989) based on macrophyte

112 and sediment characteristics. The two eastern sites (Region "C," Fig. 1) were characterized by a

113 sparse, short Thalassia testudinum canopy with some calcareous green macroalgae, primarily

114 Penicillus spp., and occurred in an area of severe P-limitation (Fourqurean and Zieman 2002). 
115 The middle two sites (Region "B") occurred in a region of intermediate P-limitation (Fourqurean 116 and Zieman 2002) but varied in their vegetation characteristics. The easternmost of these sites

117 (B2) had vegetation characteristics similar to those in region $\mathrm{C}$, while the westernmost site (B1)

118 featured a dense, tall $\underline{\text { T. testudinum }}$ canopy and little macroalgae. The westernmost two sites

119 (Region "A") were located in a region that may experience both $\mathrm{N}$ - and P-limitation. The eastern

120 site in region A (A2) had vegetation characteristics similar to site B1. The western site (A1) was

121 characterized by a dense macroalgal-Syringodium filiforme (manatee grass)- $\underline{\text {. testudinum }}$

122 assemblage. At each site we established $240.25 \mathrm{~m}^{2}$ study plots demarcated with a PVC frame

123 secured to the benthos at one meter intervals.

124 We randomly assigned treatments [control $(\mathrm{C})$, nitrogen only $(\mathrm{N})$, phosphorus only $(\mathrm{P})$, both

125 nitrogen and phosphorus (NP)] to six plots per site (at site A1, $n=3$ due to the loss of 12 plots

126 from erosion and boat disturbance over the course of the study). Nitrogen was added in the form

127 of slow release nitrogen fertilizer (Polyon ${ }^{\mathrm{TM}}$, Pursell Technologies Inc., 38-0-0, 94\% N as urea)

128 and phosphorus as granular phosphate rock (Multifos ${ }^{\mathrm{TM}}$, IMC Global, $\left.\mathrm{Ca}_{3}\left(\mathrm{PO}_{4}\right)_{2}, 18 \% \mathrm{P}\right)$.

129 Loading rates of $1.43 \mathrm{~g} \mathrm{~N} \mathrm{~m}^{-2}$ day $^{-1}$ and $0.18 \mathrm{~g} \mathrm{P} \mathrm{m}^{-2}$ day $^{-1}$ (molar $\mathrm{N}: \mathrm{P}$ ratio 17.6:1) were selected

130 based on potential sewage loading rates (MCSM 2001) and previous studies in the region (Ferdie 131 and Fourqurean 2004). We began bimonthly applications of fertilizer in October 2002 by

132 sprinkling granular fertilizer evenly on the sediment surface and gently working it into the

133 sediment by hand. Sediment in the control plots was similarly disturbed but no fertilizer was

134 added. Benthic fertilizer applications ensured accessibility of nutrients to both above-ground and

135 benthic primary producers (Ferdie and Fourqurean 2004; Mutchler et al. 2004).

136 In February 2004 we determined sediment, seagrass tissue, and seagrass epiphyte $\mathrm{N}$ and $\mathrm{P}$

137 content to assess the effectiveness of the enrichment treatments. Macroalgal tissue nutrient 
138 content was not determined due to insufficient algal abundance and the occurrence of different

139 species at each site. Sediment cores (1 cm diameter, $5 \mathrm{~cm}$ deep) were collected from each plot

140 and dried at $60^{\circ} \mathrm{C}$. Two $\underline{\text { T. testudinum }}$ short-shoots were collected from each plot and the

141 epiphytes removed by gently scraping the blades with a razor blade. At site A1, nutrient content

142 of $\underline{\text { S. filiforme }}$ tissue was also determined. Nitrogen content of the sediment, epiphytes, and the

143 cleaned seagrass tissue were determined separately using a CHN analyzer (Fisons NA1500).

144 Phosphorus content was determined by a dry-oxidation, acid hydrolysis extraction followed by a

145 colorimetric analysis of phosphate concentration of the extract (Fourqurean et al. 1992).

146 Using methods based on extensive monitoring in this region (Fourqurean et al. 2002), we

147 estimated seagrass ( $\underline{\text { T. testudinum }}, \underline{\text { S. filiforme }}$, and $\underline{\text { Halodule wrightii) }}$ and macroalgal percent

148 cover with a modified Braun-Blanquet (BB) abundance scale: $0=$ absent; $0.1=$ one individual,

$149<5 \%$ cover; $0.5=$ few individuals, $<5 \%$ cover; $1=$ many individuals, $<5 \%$ cover; $2=5-25 \%$

150 cover; $3=25-50 \%$ cover; $4=50-75 \%$ cover; $5=75-100 \%$ cover. To measure $\underline{\text { T. testudinum }}$

151 productivity, two haphazardly selected short-shoots in each plot were marked at the base of the

152 leaves with an 18-gauge hypodermic needle and labeled with a cable tie for identification. We

153 collected the shoots after 11-13 days, recorded the increase in leaf lengths, and calculated

154 productivity (mg short-shoot ${ }^{-1} \mathrm{~d}^{-1}$ ). We limited our productivity measurements to two shoots to

155 minimize impact and facilitate future long-term sampling of this experiment

156 All epiphytes were removed from one short-shoot from each plot as above. Epiphytes were

157 freeze dried and pigments extracted with $90 \%$ acetone. The chlorophyll $a$ concentration was

158 determined using a Shimadzu RF-Mini 150 fluorometer with low bandwidth filters

159 (Welschmeyer 1994) following calibration with a chlorophyll $a$ standard using a Shimadzu UV 
160 Mini 1240 spectrophotometer and the spectrophotometric equations of Jeffrey and Humphrey

161 (1975).

162 To determine benthic microalgal biomass, we collected a $2.5 \mathrm{~cm}$ diameter, $1 \mathrm{~cm}$ deep core

163 haphazardly located within each plot. Sediments were freeze dried, pigments extracted with $90 \%$

164 acetone, and chlorophyll $a$ concentration determined as for the epiphytes.

165 The variances of all data were tested for homoscedasticity using the $\mathrm{F}_{\max }$ test and $\log$ 166 transformed if necessary to conform to the assumptions of ANOVA. All data were analyzed with

167 three-way split-plot ANOVA, where the factors were $\pm \mathrm{P}, \pm \mathrm{N}$, and region $(\mathrm{A}, \mathrm{B}, \mathrm{C})$ with sites

168 (A1, A2, B1, B2, C1, C2) nested within regions. Region, P, and N factors were considered fixed

169 and sites were random for this ANOVA model. The linear model for this design was:

$170 \quad$ (response variable $)_{i j k l m}=\mu+(\text { region })_{i}+(\mathrm{P} \text { addition })_{k}+(\mathrm{N} \text { addition })_{l}+($ interaction between

171 region and $\mathrm{P})_{i k}+(\text { interaction between region and } \mathrm{N})_{i l}+(\text { interaction between } \mathrm{P} \text { and } \mathrm{N})_{k l}+$

172 (interaction between region, $\mathrm{P}$, and $\mathrm{N})_{i k l}+(\text { site within region })_{j(i)}+($ interaction between site

173 within region and $\mathrm{P})_{j(i) k}+(\text { interaction between site within region and } \mathrm{N})_{j(i) l}+($ interaction

174 between site within region, $\mathrm{P}$, and $\mathrm{N})_{j(i) k l}+\varepsilon_{i j k l m}$

175 where $\mu$ is the overall mean, $\varepsilon$ is the unexplained error, $i, j, k$, and $l$ represent the levels within 176 each factor, and $m$ is the number of observations per site per nutrient treatment (Quinn and

177 Keough 2002). Site A1 was excluded from analyses of $\underline{\text { T. testudinum }}$ productivity and epiphyte 178 nutrient content due to insufficient replication, as several plots at that site contained only one $\underline{T}$.

179 testudinum short-shoot, and we prioritized the epiphyte chlorophyll $a$ and seagrass tissue nutrient 180 analyses.

$181 \quad$ Results 
182 Sediment, seagrass, and epiphyte nutrient content reflected nutrient treatments, though the

183 magnitude of the responses varied among regions and sites. Significant region*P and site*P

184 interactions for sediment \%P (Table 1) suggested that although sediment $\mathrm{P}$ content increased at

185 all sites when $\mathrm{P}$ was added, the magnitude of increase varied among sites within regions. All

186 sites had low $\mathrm{P}$ content $(<0.05 \%)$ prior to $\mathrm{P}$ addition, but sites $\mathrm{A} 2$ and $\mathrm{B} 1$ appeared to have the

187 largest increases when $\mathrm{P}$ was added (Fig. 2a). Sediment $\mathrm{N}$ content was significantly affected by

188 region, site, and $\mathrm{N}$ addition. Overall, sediment $\% \mathrm{~N}$ increased when $\mathrm{N}$ was added, but the increase

189 was generally less than $50 \%$ over control levels (Fig. 2b). Sediment N content was lower in

190 region $\mathrm{C}$ than in regions $\mathrm{A}$ and $\mathrm{B}$ and highest overall in sites $\mathrm{A} 2$ and $\mathrm{B} 1$.

191 Significant region*P and site $* \mathrm{P} * \mathrm{~N}$ interactions suggested that responses of $\underline{\text { T. testudinum }}$

192 tissue $\% \mathrm{P}$ content to nutrient treatments varied among sites within regions but that there was no

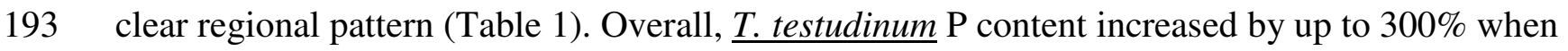

194 P was added at all sites except A1, where control and enriched levels of P were similar to each

195 other and to enriched P levels at other sites (Fig. 3a). However, at sites B2 and C2, P addition did

196 not increase tissue $\mathrm{P}$ content as much when $\mathrm{N}$ was also added. Tissue $\% \mathrm{~N}$ content significantly

197 increased in response to $\mathrm{N}$ addition, though the change was small (10-20\% increase, Fig. 3b),

198 relative to the $\mathrm{P}$ responses. Significant site*P and region*P interactions suggested that tissue $\% \mathrm{~N}$

199 content response to $\mathrm{P}$ enrichment varied among sites within regions. Tissue \% $\mathrm{N}$ content

200 increased when P was also added, but only at sites B2 and C1. In addition, at site A1, N content

201 decreased when $\mathrm{P}$ was added. Significant region*P and site*P*N interactions for $\underline{\text { T. testudinum }}$

202 molar N:P ratios closely followed the site-specific but not region-specific tissue \%P responses. In

203 control plots, the $\underline{\text { T. testudinum }}$ N:P ratio was $\sim 30: 1$ at site A1, 60:1 at sites A2 and B1, and

$204 \sim 100: 1$ at sites B2, C1, and C2 (Fig. 3c). At all sites except A1, P addition lowered $\underline{\text { T. testudinum }}$ 
$205 \mathrm{~N}: \mathrm{P}$ ratios to values approaching those at A1, though the largest relative decreases occurred at 206 sites B2 and C2. At those two sites, N:P ratios appeared to be lower when P was added alone 207 than when $\mathrm{P}$ and $\mathrm{N}$ were added together. $\underline{\text { S. filiforme }}$ tissue nutrient content did not vary with 208 nutrient treatment, but did have slightly higher P (mean $0.24 \pm 0.01 \mathrm{SE} \% \mathrm{P})$ and N $(2.45 \pm 0.09$ $209 \% \mathrm{~N})$ content and a lower N:P ratio $(22.58 \pm 1.27 \mathrm{~N}: \mathrm{P})$ than $\underline{\text { T. testudinum }}$ at site A1.

210 The nutrient content of $\underline{\text { T. testudinum }}$ epiphytes also showed complex responses to nutrient 211 addition. Significant region*P and site*P interactions for epiphyte $\mathrm{P}$ content stemmed from 212 larger increases in \% P following $\mathrm{P}$ addition at sites $\mathrm{B} 2$ and $\mathrm{C} 2$ than at the other sites with no 213 distinct regional pattern (Table 1, Fig. 4a). No epiphyte elemental analyses were performed for 214 site A1 due to insufficient $\underline{\text { T. testudinum }}$ tissue available for collection. Epiphyte $\mathrm{N}$ content was 215 lower in region $\mathrm{C}$ than in the other regions and variable among sites, with the highest content at 216 sites A2 and B1, but was not affected by nutrient addition treatment (Fig. 4b). Significant 217 region*P and site*P interactions for epiphyte molar N:P ratios were driven by large P-induced 218 decreases in N:P ratios at all sites except A2 (Fig. 4c). In addition, epiphyte N:P ratios were 219 significantly higher when $\mathrm{N}$ was added in all regions, though the magnitude of the $\mathrm{N}$ effect was 220 smaller than the P effect.

$221 \underline{\text { T. testudinum }}$ cover and productivity generally responded positively to $\mathrm{P}$ addition but were 222 unaffected by $\mathrm{N}$ addition. A significant interaction between site and $\mathrm{P}$ for $\underline{\text { T. testudinum }}$ cover 223 stemmed from large P-induced increases in cover at sites B2, C1, and C2 (Table 2, Fig 5a). The 224 strong site-specific responses of $\underline{\text { T. testudinum }}$ cover to $\mathrm{P}$ addition obscured any regional 225 patterns. At sites B2, C1, and C2, control plots had a Braun-Blanquet (BB) score of $\sim 2$, which 226 corresponds to about $25 \%$ cover. $\mathrm{P}$ addition plots had BB scores of 3 or 4 , corresponding to 50$22775 \%$ cover. $\underline{\text { T. testudinum }}$ productivity varied significantly with $\mathrm{P}$ and $\mathrm{N}$ addition but strong site- 
228 specific responses masked regional trends. Productivity increased with both $\mathrm{N}$ and $\mathrm{P}$ addition

229 relative to controls, though productivity tended to be similar between $\mathrm{P}$ and NP plots at sites B2,

$230 \mathrm{C} 1$, and C2 (Fig. 5b). In addition, productivity tended to be higher at sites A2 and B1 than at the

231 other sites. Site A1 was excluded from the productivity analysis due to insufficient $\underline{\text { T. testudinum }}$

232 tissue available for collection.

233 Two additional species of seagrass occurred at some study sites. Syringodium filiforme was

234 found in all plots at site A1 throughout the study period, but percent cover was similar across

235 nutrient treatments (average BB score $3.1 \pm 0.3$ ). Halodule wrightii colonized one NP plot at

236 both sites A2 and B1 and comprised 25-50\% cover in those plots.

237 Macroalgal cover showed group-specific responses to nutrient treatment that varied widely

238 among regions and between sites within regions. Filamentous and other uncalcified, branching

239 red algae (Div. Rhodophyta) and calcified green algae (Div. Chlorophyta) were the most

240 common groups. A significant region*P interaction suggested that cover of red macroalgae

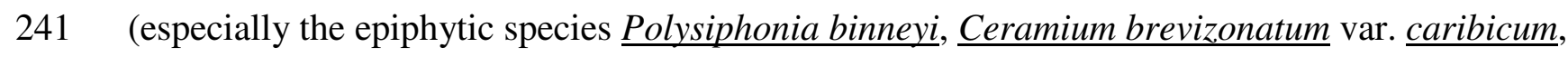

242 and Chondria sp.) increased in response to $\mathrm{P}$ addition, but primarily at sites in region C (Table 2;

243 Fig. 5c). Percent cover tended to be highest overall at site A1, and red algae were not detected at

244 site $\mathrm{B} 1$ or in the control and $\mathrm{N}$ only plots at site $\mathrm{B} 2$. A site* $\mathrm{N}$ interaction suggested that calcified

245 green macroalgal cover (especially the benthic genus Penicillus spp.) response to nutrient

246 addition differed among sites, but high variability among sites obscured regional patterns (Fig.

247 5d). A slight $\mathrm{N}$-induced increase in cover occurred at site $\mathrm{C} 2$ and a small $\mathrm{N}$-induced decrease in

248 cover occurred at site A1. Calcareous green algae were not detected at sites A2 or B1.

249 Epiphyte loads were highly variable among regions and sites and exhibited complex

250 responses to nutrient treatments. A significant site $* \mathrm{P} * \mathrm{~N}$ interactions suggested that epiphyte 
251 chlorophyll $a$ concentration exhibited strong site-specific responses to nutrients that masked

252 regional patterns (Table 2). The highest chlorophyll $a$ concentrations occurred at sites A1 and B2

253 (Fig. 5e). There was a strong decrease in chlorophyll $a$ in the $\mathrm{P}$ and NP treatments at site B2, an

254 increase in the P and NP treatments at site $\mathrm{C} 1$, and no nutrient effects at sites A1, A2, B1, or C2.

255 Benthic microalgal biomass, as estimated by benthic chlorophyll $a$ concentration, exhibited

256 region-specific but generally weak responses to $\mathrm{P}$ addition, as suggested by a significant

257 region*P interaction (Table 2). $\mathrm{P}$ addition slightly increased benthic chlorophyll $a$ in region $\mathrm{C}$

258 (Fig. 5f). Similar trends occurred in region A, though variability was high at site A1. Benthic

259 microalgal biomass did not respond to $\mathrm{P}$ addition treatment at sites in region $\mathrm{B}$, and no $\mathrm{N}$ effects

260 were detected throughout the bay. A significant site effect stemmed from higher benthic

261 chlorophyll $a$ concentrations at sites A1 and B2 than the other sites.

\section{Discussion}

263 Stoichiometric evidence from seagrass tissue N:P ratios suggests widespread phosphorus

264 limitation in tropical seagrass communities on carbonate sediments (Atkinson and Smith 1983;

265 Fourqurean et al. 1992). This prediction has been corroborated by experimental evidence that

266 demonstrated positive seagrass responses to $\mathrm{P}$ addition (Short et al. 1985) and low porewater $\mathrm{P}$

267 concentration in carbonate sediments (McGlathery et al. 2001). P-limitation in these cases may

268 be attributed to the adsorption of phosphate to carbonate sediments (Koch et al. 2001) and the

269 augmentation of $\mathrm{N}$ supply through nitrogen fixation in systems like Florida Bay with long water

270 residence times (Howarth 1988). Accordingly, in our study there was little evidence for $\mathrm{N}$

271 limitation for any of the benthic primary producers throughout the bay. This agrees with

272 predictions from studies of seagrass tissue nutrient content, which suggest that $\% \mathrm{~N}$ content above

$2731.8 \%$ indicates that $\mathrm{N}$ is not limiting (Duarte 1990), and seagrass tissue $\% \mathrm{~N}$ at all of our study 
274 sites was $\sim 2 \%$. However, we underestimated the complexity of the benthic primary producer

275 responses to $\mathrm{P}$ enrichment. Recent work finds that there is no general pattern of P-limitation on

276 carbonate sediments (Ferdie and Fourqurean 2004), possibly due to an active dissolution of

277 carbonate sediments in the rhizosphere of seagrass beds (Burdige and Zimmerman 2002),

278 making P sorbed to sediments available for root uptake (Jensen et al. 1998). Thus, relative supply

279 of $\mathrm{N}$ and $\mathrm{P}$ are probably the most important determinants of the limiting nutrient, even in

280 carbonate sediments (Erftemeijer et al. 1994).

$281 \quad \underline{\text { T.testudinum }}$ responses to $\mathrm{P}$ enrichment exhibited strong site-specific variation that

282 corresponded with the ambient seagrass N:P ratio at each site but did not follow the regional

283 patterns we expected. The eastern bay was severely P-limited, as indicated by the high $(\sim 100: 1)$

284 seagrass N:P ratios in unenriched plots, and P addition caused marked increases in seagrass

285 cover and growth. However, the impacts of $\mathrm{P}$ addition were not restricted to the two sites in

286 region C; site B2 had a similarly high ambient N:P ratio and increase in cover and productivity

287 following $\mathrm{P}$ enrichment. In contrast, there was little cover or growth response to $\mathrm{P}$ addition in the

288 three western sites, despite tissue P content that fell well below the $0.2 \%$ DW threshold that

289 suggests P limitation (Duarte 1990) at all sites except A1. Variation in growth responses was

290 introduced by sampling only two shoots per plot in order to preserve the integrity of the canopy

291 and facilitate future observations in this long term study, but relative differences among sites

292 suggest that productivity responses to nutrients were much less pronounced in the western than

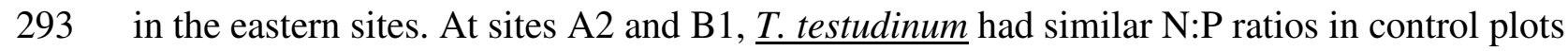

294 ( 60:1) and exhibited similar responses to nutrient addition, despite the presence of a large,

295 shallow bank between the two sites that limited oceanic and Gulf of Mexico water input to the

296 Interior Bay region (region B). It is not unusual to encounter site-specific patterns of nutrient 
297 limitations in tropical seagrass communities (Agawin et al. 1996; Udy and Dennison 1997), but

298 the spatial complexity we encountered did not follow topographic contours as we expected.

299 Further complexity in responses to P enrichment was revealed by the generally weak micro-

300 and macroalgal responses to nutrient addition throughout the bay. Epiphytic and macroalgal

301 overgrowth of seagrass frequently occurs in nutrient enriched conditions in both temperate

302 (Valiela et al. 1997; Hauxwell et al. 2001; Cardoso et al. 2004) and tropical (Tomasko and

303 Lapointe 1991; McGlathery 2001) habitats, yet this expected algal proliferation did not occur in

304 our study. In fact, a decrease in epiphyte load occurred in P-addition treatments at site B2.

305 Increased $\underline{\text { T. testudinum }}$ leaf productivity may have reduced leaf life span and decreased the

306 amount of time for epiphyte accumulation, a pattern similar to that seen in N-limited seagrass

307 beds offshore from the Florida Keys (Ferdie and Fourqurean 2004). However, differences in $\underline{T}$.

308 testudinum specific leaf productivity in Florida Bay account for less variation in epiphyte loading

309 than grazer abundance and nutrients (Frankovich and Zieman 2005), suggesting that increased

310 leaf productivity in enriched plots at site B2 only partially explains lower epiphyte loads. Benthic

311 microalgal biomass can also increase in enriched conditions (Nilsson et al. 1991), but we

312 detected little microphytobenthic response. Although we disturbed the sediments every two

313 months during the addition of fertilizer, our activities were unlikely to obscure microalgal

314 responses to nutrient addition because benthic microalgae are often dominated by biraphid

315 pennate diatoms that have well-developed motility, allowing rapid migration back to the

316 sediment surface following small-scale bioturbation events (Admiraal 1984). It is possible that

317 the lack of response of the epiphytic and macroalgal primary producers may have been a result of

318 the mode of nutrient delivery via fertilization of the sediments. It has been suggested that

319 seagrass epiphytes and some macroalgae are unable to utilize sediment nutrient pools 
320 (Erftemeijer et al. 1994). In our study, substantial portions of the added nutrients, particularly

321 phosphorus, were retained in the sediment, but we did elicit changes in the nutrient content and

$322 \mathrm{~N}: \mathrm{P}$ ratios of the seagrass and epiphyte assemblages in a pattern consistent with increased $\mathrm{N}$ and

323 P availability in fertilized plots. Furthermore, Ferdie and Fourqurean (2004) used an identical

324 fertilization protocol in higher energy sites near the Florida Barrier Reef and detected nitrogen

325 responses in both seagrass and epiphytes, demonstrating that this fertilization technique was

326 effective in enriching both benthic and aboveground producers. Thus, the unexpected lack of

327 responses to $\mathrm{P}$ addition by both seagrass and algae in seemingly P-limited habitats was probably

328 not due to inaccessibility of the added nutrients but was the likely result of multiple alternative

329 biotic and abiotic factors.

330 Phosphorus storage in seagrass and algal tissue without subsequent growth or other

331 morphological responses at some sites suggests that another nutrient may have been regulating

332 plant growth. Iron availability may limit seagrasses or algal assemblages, particularly those in

333 carbonate sediments (Duarte et al. 1995). However, experimental Fe additions have yielded few

334 micro- or macroalgal (Kuffner and Paul 2001) or seagrass (Chambers et al. 2001) responses in

335 tropical habitats. Silica availability can control diatom growth when $\mathrm{N}$ and $\mathrm{P}$ are in excess

336 (Carrick and Lowe 1988). This mechanism may have been important in the benthic microalgal

337 community in our study, which is diatom-dominated (Lewis et al. 2000), but Florida Bay

338 seagrass epiphyte loads are typically dominated by calcium carbonate (coralline algae and

339 adhered sediment) rather than diatoms (Frankovich and Zieman 1994), so silica availability

340 probably did not limit epiphyte responses to $\mathrm{N}$ and $\mathrm{P}$ addition.

341 Competition for other limiting resources, such as light (Ibarra-Obando et al. 2004) and space

342 (Marbà and Duarte 2003) may have prevented primary producers from responding to P addition 
343 in the western portions of the bay. Sites A2 and B1 were generally less turbid than sites in the

344 eastern bay, but $\underline{\text { T. testudinum }}$ shoot densities at those sites ( $500-800$ short-shoots $\left.\mathrm{m}^{-2}\right)$

345 approached the maxima recorded in other studies in this region (Zieman et al. 1999), suggesting

346 that the canopy may have been saturated and that self-shading was occurring. In addition,

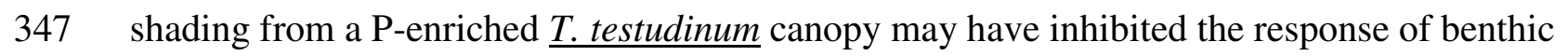

348 microalgae to enriched conditions across all sites.

349 Grazing can structure temperate and tropical seagrass communities through direct

350 consumption of seagrass (McGlathery 1995; Valentine and Heck 2001), controlling epiphyte

351 growth (Williams and Ruckelshaus 1993; Heck et al. 2000), and regulating benthic microalgal

352 production (Nilsson et al. 1991). Therefore, grazing pressure may have limited $\underline{\text { T. testudinum }}$ and

353 algal responses to excess nutrients at the middle bay sites and algal responses throughout the bay.

354 Grazers known to regulate epiphyte assemblages, including snails (van Montfrans et al. 1982)

355 and grass shrimp (Zupo and Nelson 1999) are frequently found in Florida Bay (McClanahan

356 1992; Matheson et al. 1999; Frankovich and Zieman 2005). Preferential grazing on nutrient-

357 enriched plant tissue, a pattern observed in algal (Boyer et al. 2004) and seagrass assemblages

358 (McGlathery 1995), may compensate for nutrient-induced increases in plant biomass. Though

359 this may have contributed to the control of nutrient-induced micro- or macroalgal growth, the

360 most common seagrass grazer in Florida Bay, the pink urchin Lytechinus variegatus, does not

361 exhibit a preference for nutrient-enriched seagrass (McGlathery 1995; Valentine and Heck 2001)

362 and was seldom observed in the study areas (Armitage et al., unpub. data) and was therefore

363 unlikely to mitigate $\underline{\text { T. testudinum }}$ response to nutrients.

364 Species-specific seasonal fluctuations in primary producer biomass and productivity may

365 result in temporally variable responses to excess nutrients. Wintertime peaks in epiphyte 
366 (Frankovich and Zieman 1994) and rhodophyte (Collado-Vides et al. 1994) biomass in tropical

367 regions suggest that algal responses to nutrient enrichment might have been most pronounced at

368 the time of year of our sampling effort. Our continued monitoring of this project supports this

369 assertion, as the proliferations of red algae in $\mathrm{P}$ addition treatments in the eastern bay had largely

370 senesced by May 2004 (Armitage et al., unpub. data). In addition, we monitored this experiment

371 on a bimonthly basis since its inception and no qualitative algal proliferations were observed at

372 any time in this study until our sampling in February 2004, further suggesting that the macroalgal

373 responses were ephemeral.

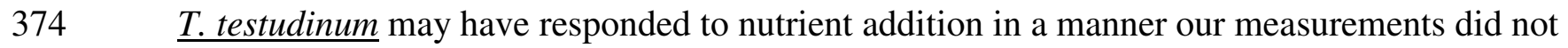

375 detect because belowground characteristics were not sampled in order to minimize impact and

376 facilitate future long-term sampling of this experiment. Thus, it is possible that nutrient addition

377 was disproportionately allocated to the root/rhizome complex, particularly at sites A2 and B1,

378 where no aboveground response was detected. However, fertilizer-induced changes in shoot:root

379 allocation generally result from an increase in shoot biomass (Lee and Dunton 2000).

380 Alternatively, excess P may have been translocated along the rhizome system to new growth

381 outside the treatment plot (Marbà et al. 2002) and was thus undetected in our sampling protocol,

382 though our qualitative observations suggest that the fertilization effects were strongly localized

383 around the treatment plots.

384 The western site with an ambient $\underline{\text { T. testudinum }}$ tissue N:P ratio of 30:1 was not affected by $\mathrm{N}$

385 or P addition, suggesting a balance between $\mathrm{N}$ and $\mathrm{P}$ supply (Atkinson and Smith 1983).

386 Accordingly, T. testudinum tissue phosphorus content at that site was high (Duarte 1990), and

387 the diverse macroalgal assemblage and the abundance of Syringodium filiforme, a seagrass

388 species associated with enriched conditions (Ferdie and Fourqurean 2004), reflected the elevated 
389 nutrient supply. However, this site was heavily impacted by factors other than nutrient supply,

390 particularly frequent disturbances, both through current and erosion processes as well as boat

391 traffic, illustrating the range of factors that may regulate benthic primary producer assemblages.

392 The replacement of slower growing species with more opportunistic ones in nutrient enriched

393 conditions is a commonly observed occurrence in terrestrial (Bargali 1997), freshwater (Craft

394 and Richardson 1997), and marine habitats (Duarte 1995; Valiela et al. 1997; McGlathery 2001).

395 However, in our study, there was no suggestion of macroalgal replacement of seagrass, possibly

396 due to the seasonal nature of macroalgae in Florida Bay. Shoalgrass Halodule wrightii began to

397 colonize some of the NP plots, and though its occurrence was patchy at the time of this study,

398 continued fertilization may eventually lead to $\underline{H}$. wrightii replacement of $\underline{T \text {. testudinum, a }}$

399 phenomenon observed following two years of increased nutrient supply in a separate study in

400 Florida Bay (Fourqurean et al. 1995).

401 Our results bear directly on the hypothesis that increased freshwater, and therefore $\mathrm{N}$ loading

402 from the Everglades ecosystem as a result of restoration efforts could change the nature of

403 seagrass communities of Florida Bay (Brand 2002; Lapointe and Barile 2004). Direct addition of

404 P to eastern Florida Bay seagrass beds caused marked changes in community structure in the

405 short time course of our experiments, but $\mathrm{N}$ addition had almost no impact on primary producers

406 in any region of the Bay. These results suggest that an increase in N loading to Florida Bay

407 would have very little direct impact on seagrass communities. However, some bioassay

408 experiments have shown N limitation within the western Bay phytoplankton communities

409 (Lavrentyev et al. 1998; Tomas et al. 1999), so it is still possible that N loading could negatively

410 impact seagrass communities by promoting phytoplankton growth, leading to light limitation of

411 benthic plants. The spatial scale of our experiments was not appropriate for testing this idea, as 
412 any phytoplankton bloom stimulated in our small study plots would have quickly been washed

413 away. Further, as the seagrass communities of the adjacent Florida Keys National Marine

414 Sanctuary are N-limited (Ferdie and Fourqurean 2004), increases in N loading to Florida Bay

415 could have an effect on the adjacent, downstream communities without directly altering seagrass

416 communities within the Bay.

417 Stoichiometric ratios are widely used to predict nutrient limitation, where a N:P ratio of 30:1

418 represents the modified Redfield ratio for seagrasses (e.g., Atkinson and Smith 1983; Fourqurean

419 and Zieman 2002). However, our study adds to the growing body of evidence that although very

420 high or very low stoichiometric ratios represent $\mathrm{P}$ or $\mathrm{N}$ (respectively) limitation, a broad middle

421 range of $\mathrm{N}: \mathrm{P}$ ratios ( 20-60:1) does not yield consistent predictions of patterns of nutrient

422 limitation in seagrasses. Although the breadth of that middle range might be a function of the

423 relatively short time period of this study, several experimental studies provide further support for

424 this conclusion. For example, four species of seagrass in Australia had similar ( 20:1) molar N:P

425 ratios, but each species exhibited a unique response to $\mathrm{N}$ and $\mathrm{P}$ addition: strong $\mathrm{N}$ limitation,

426 weak $\mathrm{N}$ limitation, $\mathrm{N}$ and $\mathrm{P}$ balance, and no nutrient response were all observed (Udy and

427 Dennison 1997; Udy et al. 1999). In another study on the ocean side of the Florida Keys,

428 seagrass tissue N:P ratios ( 40:1) suggested P-limitation in nearshore seagrass beds (Fourqurean

429 and Zieman 2002). However, experimental nutrient enrichment demonstrated N-limitation in the

430 macro- and microalgae but few effects of $\mathrm{N}$ or $\mathrm{P}$ enrichment on the seagrass (Ferdie and

431 Fourqurean 2004), illustrating that predictions of nutrient limitation from stoichiometric ratios

432 may not apply uniformly to all primary producers within a community. In addition, other biotic

433 or abiotic factors, such as grazing pressure, space, or the level of disturbance, may exert strong

434 influences on primary producer responses to nutrient enrichment. Supplementing stoichiometric 
435 field assays with experimental manipulations will enable more accurate predictions of the

436 impacts of nutrient enrichment on coastal habitats.

437 Acknowledgements

438 This research was funded by a grant from the Everglades National Park under cooperative 439 agreement 1443CA528001022, by the Florida Coastal Everglades Long Term Ecological

440 Research Program funded by the US National Science Foundation (Cooperative Agreement 441 \#DEB-9910514), and by the Alabama Center for Estuarine Studies. Doug Morrison and Bill

442 Perry facilitated permit issuance and use of ENP facilities. We thank the many people who 443 devoted time to this project, particularly Amy Willman, Susie Escorcia, Cecie Gordon, Megan

444 Balkenbush, Melissa Cumberbatch, Bryan Dewsbury, and Ligia Collado. Pursell Technologies

445 Inc. and IMC Global generously donated the nitrogen and phosphorus fertilizers, respectively, 446 for this study. This is contribution number XXX from the Southeast Environmental Research 447 Center.

Admiraal, W. 1984. The ecology of sediment-inhabiting diatoms. Progress on Phycological

$452 \underline{\text { Research } 3 .}$

453 Agawin, N. S. R., C. M. Duarte, and M. D. Fortes. 1996. Nutrient limitation of Philippine 454 seagrasses (Cape Bolinao, NW Philippines): in situ experimental evidence. Marine $455 \quad$ Ecology Progress Series 138:233-243.

456 Atkinson, M. J. and S. V. Smith. 1983. C:N:P ratios of benthic marine plants. Limnology and $457 \quad$ Oceanography 28:568-574. 
Bargali, K. 1997. Role of light, moisture and nutrient availability in replacement of Quercus leucotrichophora by Pinus roxburghii in Central Himalaya. Journal of Tropical Forest Science 10:262-270.

Borum, J. and K. Sand-Jensen. 1996. Is total primary production in shallow coastal marine waters stimulated by nitrogen loading? Oikos 76:406-410.

Boyer, K. E., P. Fong, A. R. Armitage, and R. A. Cohen. 2004. Elevated nutrient content of tropical macroalgae increases rates of herbivory in coral, seagrass, and mangrove habitats. Coral Reefs 23:530-538.

Brand, L. E. 2002. The transport of terrestrial nutrients to South Florida coastal waters, p. 361411. In J. W. Porter and K. G. Porter (eds.), The Everglades, Florida Bay, and coral reefs of the Florida Keys: an Ecosystem Sourcebook. CRC Press, Boca Raton.

Burdige, D. J. and R. C. Zimmerman. 2002. Impact of sea grass density on carbonate dissolution in Bahamian sediments. Limnology and Oceanography 47:1751-1763.

Cardoso, P. G., M. A. Pardal, A. I. Lillebø, S. M. Ferreira, D. Raffaelli, and J. C. Marques. 2004. Dynamic changes in seagrass assemblages under eutrophication and implications for recovery. Journal of Experimental Marine Biology and Ecology 302:233-248.

Carrick, H. J. and R. L. Lowe. 1988. Response of Lake Michigan benthic algae to in situ enrichment with silicon, nitrogen, and phosphorus. Canadian Journal of Fisheries and Aquatic Sciences 45:271-279.

Chambers, R. M., J. W. Fourqurean, S. A. Macko, and R. Hoppenot. 2001. Biogeochemical effects of iron availability on primary producers in a shallow marine carbonate environment. Limnology and Oceanography 46:1278-1286. 
480 Collado-Vides, L., J. González-González, and M. Gold-Morgan. 1994. A descriptive approach to 481 the floating masses of algae of a Mexican Caribbean coastal lagoon. Botanica Marina $482 \quad 37: 391-396$.

483 Craft, C. B. and C. J. Richardson. 1997. Relationships between soil nutrients and plant species 484 composition in Everglades peatlands. Journal of Environmental Quality 26:224-232.

485 Duarte, C. M. 1990. Seagrass nutrient content. Marine Ecology Progress Series 67:201-207.

486 Duarte, C. M. 1995. Submerged aquatic vegetation in relation to different nutrient regimes.

$487 \quad$ Ophelia 41:87-112.

488 Duarte, C. M., M. Merino, and M. Gallegos. 1995. Evidence of iron deficiency in seagrasses growing above carbonate sediments. Limnology and Oceanography 40:1153-1158.

490 Erftemeijer, P. L. A., J. Stapel, M. J. E. Smekens, and W. M. E. Drossaert. 1994. The limited effect of in situ phosphorus and nitrogen additions to seagrass beds on carbonate and terrigenous sediments in South Sulawesi, Indonesia. Journal of Experimental Marine Biology and Ecology 182:123-140.

494 Ferdie, M. and J. W. Fourqurean. 2004. Responses of seagrass communities to fertilization along a gradient of relative availability of nitrogen and phosphorus in a carbonate environment.

497 Fong, P., K. E. Boyer, K. Kamer, and K. A. Boyle. 2003. Influence of initial tissue nutrient status of tropical marine algae on response to nitrogen and phosphorus additions. Marine Ecology Progress Series 262:111-123.

500 Fourqurean, J. W., M. J. Durako, M. O. Hall, and L. N. Hefty. 2002. Seagrass distribution in 501 South Florida: a multi-agency coordinated monitoring program, p. 497-522. In J. W. 
Porter and K. G. Porter (eds.), The Everglades, Florida Bay, and coral reefs of the Florida Keys: an Ecosystem Sourcebook. CRC Press, Boca Raton.

504 Fourqurean, J. W., R. D. Jones, and J. C. Zieman. 1993. Processes influencing water column nutrient characteristics and phosphorus limitation of phytoplankton biomass in Florida Bay, FL, USA: inferences from spatial distributions. Estuarine, Coastal and Shelf Science

Fourqurean, J. W., G. V. N. Powell, W. J. Kenworthy, and J. C. Zieman. 1995. The effects of long-term manipulation of nutrient supply on competition between the seagrasses Thalassia testudinum and Halodule wrightii in Florida Bay. Oikos 72:349-358.

511 Fourqurean, J. W. and J. C. Zieman. 2002. Nutrient content of the seagrass Thalassia testudinum reveals regional patterns of relative availability of nitrogen and phosphorus in the Florida

514 Fourqurean, J. W., J. C. Zieman, and G. V. N. Powell. 1992. Phosphorus limitation of primary production in Florida Bay: evidence from $\mathrm{C}: \mathrm{N}: \mathrm{P}$ ratios of the dominant seagrass Thalassia testudinum. Limnology and Oceanography 37:162-171.

517 Frankovich, T. A. and J. C. Zieman. 1994. Total epiphyte and epiphytic carbonate production of Thalassia testudinum across Florida Bay. Bulletin of Marine Science 54:679-695.

519 Frankovich, T. A. and J. C. Zieman. 2005. Grazer dynamics, nutrients, and seagrass leaf controls on epiphyte loading. Estuaries 28:In press.

521 Hauxwell, J., J. Cebrian, C. Furlong, and I. Valiela. 2001. Macroalgal canopies contribute to eelgrass (Zostera marina) decline in temperate estuarine ecosystems. Ecology 82:10071022. 
524 Heck, K. L., Jr., J. R. Pennock, J. F. Valentine, L. D. Coen, and S. A. Sklenar. 2000. Effects of 525 nutrient enrichment and small predator density on seagrass ecosystems: an experimental assessment. Limnology and Oceanography 45:1041-1057.

527 Howarth, R. W. 1988. Nutrient limitation of net primary production in marine ecosystems, p. 89110. In R. F. Johnston (ed.), Annual Review of Ecology and Systematics. Annual Reviews, Inc., Palo Alto, CA.

Ibarra-Obando, S. E., K. L. J. Heck, and P. M. Spitzer. 2004. Effects of simultaneous changes in light, nutrients, and herbivory levels, on the structure and function of a subtropical turtlegrass meadow. Journal of Experimental Marine Biology and Ecology 301:193-224.

Jeffrey, S. W. and G. F. Humphrey. 1975. New spectrophotometric equations for determining

Jensen, H. S., K. J. McGlathery, R. Marino, and R. W. Howarth. 1998. Forms and availability of sediment phosphorus in carbonate sand of Bermuda seagrass beds. Limnology and Oceanography 43:799-810.

Kennish, M. J. 2002. Environmental threats and environmental future of estuaries. Environmental Conservation 29:78-107.

541 Koch, M. S., R. E. Benz, and D. T. Rudnick. 2001. Solid-phase phosphorus pools in highly organic carbonate sediments of northeastern Florida Bay. Estuarine, Coastal and Shelf

544 Kuffner, I. B. and V. J. Paul. 2001. Effects of nitrate, phosphate and iron on the growth of macroalgae and benthic cyanobacteria from Cocos Lagoon, Guam. Marine Ecology Progress Series 222:63-72. 
547 Lapointe, B. E. 1989. Macroalgal production and nutrient relations in oligotrophic areas of $548 \quad$ Florida Bay. Bulletin of Marine Science 44:312-323.

549 Lapointe, B. E. and P. J. Barile. 2004. Comment on J. C. Zieman, J. W. Fourqurean, and T. A $550 \quad$ Frankovich. "Seagrass die-off in Florida Bay: long-term trends in abundance and growth of turtle grass, Thalassia testudinum." 1999. Estuaries 22:460-470. Estuaries 27:157-164.

552 Larned, S. T. 1998. Nitrogen- versus phosphorus-limited growth and sources of nutrients for 553 coral reef macroalgae. Marine Biology 132:409-421.

554 Lavrentyev, P. J., H. A. Bootsma, T. H. Johengen, J. F. Cavaletto, and W. S. Gardner. 1998.

555 Microbial plankton response to resource limitation: insights from the community structure and seston stoichiometry in Florida Bay, USA. Marine Ecology Progress Series $165: 45-57$.

Lee, K.-S. and K. H. Dunton. 2000. Effects of nitrogen enrichment on biomass allocation, growth, and leaf morphology of the seagrass Thalassia testudinum. Marine Ecology Progress Series 196:39-48.

561 Lewis, M. A., D. E. Weber, L. R. Goodman, R. S. Stanley, W. G. Craven, J. M. Patrick, R. L.

562 Quarles, T. H. Roush, and J. M. Macauley. 2000. Periphyton and sediment bioassessment in north Florida Bay. Environmental Monitoring and Assessment 65:503-522.

564 Marbà, N. and C. M. Duarte. 2003. Scaling of ramet size and spacing in seagrasses: implications for stand development. Aquatic Botany 77:87-98.

566 Marbà, N., M. A. Hemminga, M. A. Mateo, C. M. Duarte, Y. E. M. Mass, J. Terrados, and E.

567 Gacia. 2002. Carbon and nitrogen translocation between seagrass ramets. Marine

$568 \quad$ Ecology Progress Series 226:287-300. 
569 Matheson, R. E., Jr., D. K. Camp, S. M. Sogard, and K. A. Bjorgo. 1999. Changes in seagrassassociated fish and crustacean communities on Florida Bay mud banks: the effects of recent ecosystem changes? Estuaries 22:534-551.

572 McClanahan, T. R. 1992. Epibenthic gastropods of the Middle Florida Keys: the role of habitat and environmental stress on assemblage composition. Journal of Experimental Marine Biology and Ecology 160:169-190.

575 McGlathery, K. J. 1995. Nutrient and grazing influences on a subtropical seagrass community. Marine Ecology Progress Series 122:239-252.

577 McGlathery, K. J. 2001. Macroalgal blooms contribute to the decline of seagrass in nutrientenriched coastal waters. Journal of Phycology 37:453-456.

579 McGlathery, K. J., P. Berg, and R. Marino. 2001. Using porewater profiles to assess nutrient availability in seagrass-vegetated carbonate sediments. Biogeochemistry 56:239-263.

581 MCSM. 2001. Monroe County Stormwater Management Master Plan; Volume 1; Section 2.3; Pollution loads targets and analysis.

583 Moncreiff, C. A., M. J. Sullivan, and A. E. Daehnick. 1992. Primary production dynamics in seagrass beds of Mississippi Sound: the contributions of seagrass, epiphytic algae, sand ambiguities in coastal trophic relationships. Marine Ecology Progress Series 266:27-33.

588 Nilsson, P., B. Jonsson, I. Lindstrom, and K. Sundbäck. 1991. Response of a marine shallowwater sediment system to an increased load of inorganic nutrients. Marine Ecology Progress Series 71:275-290. 
591 Nixon, S. W. 1995. Coastal marine eutrophication: a definition, social causes, and future

592 concerns. Ophelia 41:199-219.

593 Powell, G. V. N., W. J. Kenworthy, and J. W. Fourqurean. 1989. Experimental evidence for

594 nutrient limitation of seagrass growth in a tropical estuary with restricted circulation.

$595 \quad$ Bulletin of Marine Science 44:324-340.

596 Quinn, G. P. and M. J. Keough. 2002. Experimental Design and Data Analysis for Biologists.

597 Cambridge University Press, Cambridge.

598 Rudnick, D. T., Z. Chen, D. L. Childers, J. N. Boyer, and T. D. Fontaine, III. 1999. Phosphorus

599 and nitrogen inputs to Florida Bay: the importance of the Everglades watershed. Estuaries

$600 \quad 22: 398-416$.

601 Short, F. T., M. W. Davis, R. A. Gibson, and C. F. Zimmermann. 1985. Evidence for phosphorus

602 limitation in carbonate sediments of the seagrass Syringodium filiforme. Estuarine,

$603 \quad$ Coastal and Shelf Science 20:419-430.

604 Smith, V. H., G. D. Tilman, and J. C. Nekola. 1999. Eutrophication: impacts of excess nutrient

605 inputs on freshwater, marine, and terrestrial ecosystems. Environmental Pollution

$606 \quad 100: 179-196$.

607 Tomas, C. R., B. Bendis, and K. Johns. 1999. Role of nutrients in regulating plankton blooms in

608 Florida Bay, p. 323-337. In H. Kumpf, K. Steidinger, and K. Sherman (eds.), The Gulf of

609 Mexico Large Marine Ecosystem. Blackwell Science, Malden, Massachussetts.

610 Tomasko, D. A. and B. E. Lapointe. 1991. Productivity and biomass of Thalassia testudinum as

611 related to water column nutrient availability and epiphyte levels: field observations and

612 experimental studies. Marine Ecology Progress Series 75:9-17. 
613 Udy, J. W. and W. C. Dennison. 1997. Growth and physiological responses of three seagrass

614 species to elevated sediment nutrients in Moreton Bay, Australia. Journal of

$615 \quad$ Experimental Marine Biology and Ecology 217:253-277.

616 Udy, J. W., W. C. Dennison, W. J. Lee Long, and L. J. McKenzie. 1999. Responses of seagrass

617 to nutrients in the Great Barrier Reef, Australia. Marine Ecology Progress Series

$618 \quad 185: 257-271$.

619 Valentine, J. F. and K. L. Heck, Jr. 2001. The role of leaf nitrogen content in determining

620 turtlegrass (Thalassia testudinum) grazing by a generalized herbivore in the northeastern

621 Gulf of Mexico. Journal of Experimental Marine Biology and Ecology 258:65-86.

622 Valiela, I., J. McClelland, J. Hauxwell, P. J. Behr, D. Hersh, and K. Foreman. 1997. Macroalgal

623 blooms in shallow estuaries: controls and ecophysiological and ecosystem consequences.

$624 \quad$ Limnology and Oceanography 42:1105-1118.

625 van Montfrans, J., R. J. Orth, and S. A. Vay. 1982. Preliminary studies of grazing by Bittium

626 varium on eelgrass periphyton. Aquatic Botany 14:75-89.

627 Welschmeyer, N. A. 1994. Fluorometric analysis of chlorophyll $a$ in the presence of chlorophyll

$628 \quad b$ and pheopigments. Limnology and Oceanography 39:1985-1992.

629 Williams, S. L. and M. H. Ruckelshaus. 1993. Effects of nitrogen availability and herbivory on

$630 \quad$ eelgrass (Zostera marina) and epiphytes. Ecology 74:904-918.

631 Zieman, J. C., J. W. Fourqurean, and T. A. Frankovich. 1999. Seagrass die-off in Florida Bay:

632 long-term trends in abundance and growth of turtle grass, Thalassia testudinum. Estuaries

$633 \quad 22: 460-470$. 
634 Zieman, J. C., J. W. Fourqurean, and R. L. Iverson. 1989. Distribution, abundance and productivity of seagrasses and macroalgae in Florida Bay. Bulletin of Marine Science 44:292-311.

637 Zupo, V. and W. G. Nelson. 1999. Factors influencing the association patterns of Hippolyte 638 zostericola and Palaemonetes intermedius (Decapoda: Natantia) with seagrasses of the 639 Indian River Lagoon, Florida. Marine Biology 134:181-190.

640 
Table 1: Results from three-way split-plot ANOVA of $\mathrm{P}, \mathrm{N}$, and bay region, with site nested within region, on $\mathrm{N}$ and $\mathrm{P}$ content of the sediment, Thalassia testudinum tissue, and epiphytes.

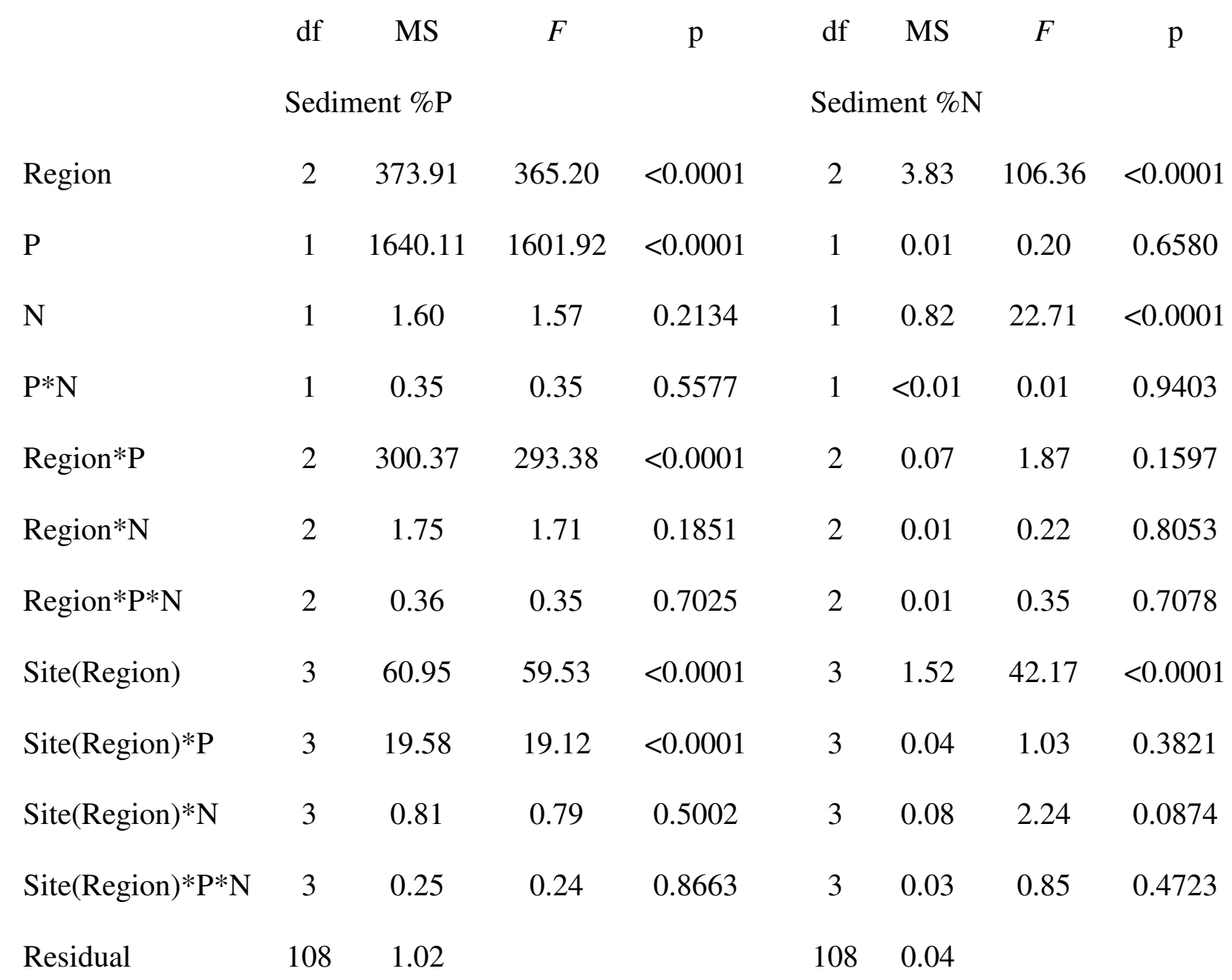


Armitage et al.

Table 1 (cont.):

\begin{tabular}{|c|c|c|c|c|c|c|c|c|c|c|c|c|}
\hline & df & MS & $F$ & $\mathrm{p}$ & df & MS & $F$ & $\mathrm{P}$ & df & MS & $F$ & $\mathrm{P}$ \\
\hline & T.te & udinum & $\% \mathrm{P}$ & & T.te & tudinun & $\% \mathrm{~N}$ & & T.te & udinu & $\mathrm{N}: \mathrm{P}$ & \\
\hline Region & 2 & 0.71 & 70.98 & $<0.0001$ & 2 & 0.03 & 25.73 & $<0.0001$ & 2 & 0.55 & 60.89 & $<0.0001$ \\
\hline $\mathrm{P}$ & 1 & 1.75 & 175.44 & $<0.0001$ & 1 & $<0.01$ & 2.46 & 0.1196 & 1 & 1.61 & 177.76 & $<0.0001$ \\
\hline $\mathrm{N}$ & 1 & 0.11 & 10.69 & 0.0014 & 1 & 0.01 & 8.47 & 0.0044 & 1 & 0.18 & 20.24 & $<0.0001$ \\
\hline $\mathrm{P}^{*} \mathrm{~N}$ & 1 & 0.05 & 4.67 & 0.0329 & 1 & $<0.01$ & $<0.01$ & 0.9807 & 1 & 0.05 & 5.20 & 0.0245 \\
\hline Region*P & 2 & 0.25 & 25.53 & $<0.0001$ & 2 & 0.01 & 5.93 & 0.0036 & 2 & 0.18 & 19.56 & $<0.0001$ \\
\hline Region*N & 2 & 0.01 & 1.13 & 0.3277 & 2 & $<0.01$ & 0.15 & 0.8603 & 2 & 0.01 & 1.56 & 0.2152 \\
\hline Region*P*N & 2 & 0.02 & 2.37 & 0.0985 & 2 & $<0.01$ & 0.58 & 0.5616 & 2 & 0.02 & 2.29 & 0.1059 \\
\hline Site(Region) & 3 & 0.20 & 20.13 & $<0.0001$ & 3 & 0.05 & 45.63 & $<0.0001$ & 3 & 0.41 & 45.67 & $<0.0001$ \\
\hline Site $($ Region $) * \mathrm{P}$ & 3 & 0.08 & 8.45 & $<0.0001$ & 3 & $<0.01$ & 2.72 & 0.0481 & 3 & 0.07 & 7.63 & $<0.0001$ \\
\hline Site(Region)*N & 3 & 0.01 & 0.96 & 0.4164 & 3 & $<0.01$ & 1.17 & 0.3231 & 3 & 0.01 & 1.29 & 0.2832 \\
\hline Site(Region)*P*N & 3 & 0.03 & 3.33 & 0.0225 & 3 & $<0.01$ & 0.66 & 0.5811 & 3 & 0.03 & 3.30 & 0.0233 \\
\hline Residual & 107 & 0.01 & & & 107 & $<0.01$ & & & 107 & 0.01 & & \\
\hline
\end{tabular}


Table 1 (cont.):

$\begin{array}{lllllllllllll}\text { df } & \text { MS } & F & \mathrm{p} & \mathrm{df} & \mathrm{MS} & F & \mathrm{p} & \mathrm{df} & \mathrm{MS} & F & \mathrm{p}\end{array}$

Epiphyte \%P

$\begin{array}{lcccccccccccc}\text { Region } & 2 & 0.55 & 19.24 & <0.0001 & 2 & 0.21 & 16.57 & <0.0001 & 2 & 0.12 & 6.23 & 0.0030 \\ \mathrm{P} & 1 & 1.32 & 45.93 & <0.0001 & 1 & 0.02 & 1.72 & 0.1932 & 1 & 1.13 & 56.86 & <0.0001 \\ \mathrm{~N} & 1 & 0.04 & 1.38 & 0.2427 & 1 & 0.03 & 2.02 & 0.1584 & 1 & 0.11 & 5.45 & 0.0219 \\ \mathrm{P} * \mathrm{~N} & 1 & <0.01 & 0.07 & 0.7988 & 1 & 0.04 & 2.84 & 0.0951 & 1 & 0.01 & 0.68 & 0.4127 \\ \text { Region*P } & 2 & 0.13 & 4.62 & 0.0124 & 2 & 0.01 & 0.59 & 0.5578 & 2 & 0.16 & 8.01 & 0.0006 \\ \text { Region*N } & 2 & <0.01 & 0.05 & 0.9466 & 2 & 0.01 & 1.04 & 0.3577 & 2 & <0.01 & 0.20 & 0.8217 \\ \text { Region*P*N } & 2 & <0.01 & 0.04 & 0.9638 & 2 & 0.01 & 0.96 & 0.3858 & 2 & 0.01 & 0.45 & 0.6368 \\ \text { Site(Region) } & 2 & 0.11 & 3.64 & 0.0303 & 2 & 0.07 & 5.60 & 0.0050 & 2 & 0.18 & 9.10 & 0.0003 \\ \text { Site(Region)*P } & 2 & 0.21 & 7.31 & 0.0012 & 2 & 0.03 & 1.95 & 0.1482 & 2 & 0.11 & 5.73 & 0.0046 \\ \text { Site(Region)*N } & 2 & 0.07 & 2.41 & 0.0958 & 2 & <0.01 & 0.23 & 0.7978 & 2 & 0.02 & 1.20 & 0.3069 \\ \text { Site(Region)*P*N } & 2 & 0.01 & 0.17 & 0.8445 & 2 & 0.01 & 0.37 & 0.6905 & 2 & 0.01 & 0.65 & 0.5228 \\ \text { Residual } & 87 & 0.03 & & & & 97 & 0.01 & & & & & \end{array}$




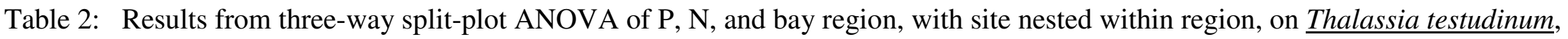
macroalgae, epiphytic microalgal, and benthic microalgal characteristics.

\begin{tabular}{|c|c|c|c|c|c|c|c|c|c|c|c|}
\hline df & MS & $F$ & $\mathrm{p}$ & $\mathrm{df}$ & MS & $F$ & $\mathrm{p}$ & df & MS & $F$ & $\mathrm{p}$ \\
\hline \multicolumn{4}{|c|}{$\underline{\text { T. testudinum Cover }}$} & \multicolumn{4}{|c|}{$\underline{\text { T. testudinum }}$ Productivity } & \multicolumn{4}{|c|}{ Rhodophyta Cover } \\
\hline 2 & 0.77 & 41.76 & $<0.0001$ & 2 & 0.42 & 9.19 & 0.0002 & 2 & 45.34 & 83.05 & $<0.0001$ \\
\hline 1 & 0.48 & 26.00 & $<0.0001$ & 1 & 1.18 & 25.85 & $<0.0001$ & 1 & 2.04 & 3.73 & 0.0560 \\
\hline 1 & $<0.01$ & 0.15 & 0.7027 & 1 & 0.31 & 6.72 & 0.0110 & 1 & 0.43 & 0.79 & 0.3767 \\
\hline 1 & $<0.01$ & 0.21 & 0.6519 & 1 & $<0.01$ & 0.03 & 0.8515 & 1 & 0.54 & 0.98 & 0.3234 \\
\hline 2 & 0.03 & 1.67 & 0.1933 & 2 & 0.05 & 1.06 & 0.3503 & 2 & 3.15 & 5.77 & 0.0042 \\
\hline 2 & 0.04 & 2.03 & 0.1359 & 2 & 0.01 & 0.19 & 0.8279 & 2 & 1.12 & 2.04 & 0.1345 \\
\hline 2 & 0.01 & 0.60 & 0.5491 & 2 & 0.08 & 1.81 & 0.1683 & 2 & 0.30 & 0.56 & 0.5753 \\
\hline 3 & 1.78 & 95.72 & $<0.0001$ & 2 & 0.56 & 12.32 & $<0.0001$ & 3 & 15.33 & 28.09 & $<0.0001$ \\
\hline 3 & 0.22 & 11.63 & $<0.0001$ & 2 & 0.05 & 1.08 & 0.3436 & 3 & 0.95 & 1.75 & 0.1613 \\
\hline 3 & $<0.01$ & 0.17 & 0.9159 & 2 & $<0.01$ & $<0.01$ & 0.9987 & 3 & 0.70 & 1.29 & 0.2826 \\
\hline 3 & 0.02 & 1.23 & 0.3023 & 2 & 0.01 & 0.14 & 0.8724 & 3 & 0.35 & 0.64 & 0.5894 \\
\hline 108 & 0.02 & & & 98 & 0.05 & & & 108 & 0.55 & & \\
\hline
\end{tabular}


Table 2 (cont.):

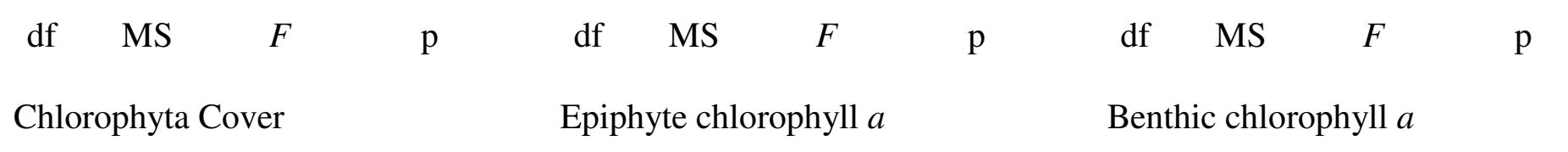

$\begin{array}{lcccccccccccc}\text { Region } & 2 & 10.33 & 72.73 & <0.0001 & 2 & 0.92 & 34.28 & <0.0001 & 2 & 0.17 & 7.97 & 0.0006 \\ \mathrm{P} & 1 & 0.01 & 0.07 & 0.7906 & 1 & 0.10 & 3.62 & 0.0598 & 1 & 0.33 & 15.23 & 0.0002 \\ \mathrm{~N} & 1 & 0.15 & 1.09 & 0.2988 & 1 & 0.02 & 0.69 & 0.4073 & 1 & 0.01 & 0.28 & 0.6000 \\ \mathrm{P} * \mathrm{~N} & 1 & 0.01 & 0.09 & 0.7594 & 1 & 0.06 & 2.09 & 0.1513 & 1 & 0.01 & 0.22 & 0.6433 \\ \text { Region*P } & 2 & 0.43 & 3.01 & 0.0532 & 2 & 0.25 & 9.39 & 0.0002 & 2 & 0.09 & 4.31 & 0.0159 \\ \text { Region*N } & 2 & 0.47 & 3.27 & 0.0417 & 2 & 0.03 & 1.08 & 0.3447 & 2 & 0.02 & 0.91 & 0.4054 \\ \text { Region*P*N } & 2 & 0.11 & 0.75 & 0.4772 & 2 & 0.03 & 0.94 & 0.3921 & 2 & 0.02 & 0.99 & 0.3760 \\ \text { Site(Region) } & 3 & 16.66 & 117.29 & <0.0001 & 3 & 4.10 & 152.69 & <0.0001 & 3 & 0.72 & 32.90 & <0.0001 \\ \text { Site(Region)*P } & 3 & 0.27 & 1.92 & 0.1312 & 3 & 0.31 & 11.56 & <0.0001 & 3 & 0.02 & 0.79 & 0.5033 \\ \text { Site(Region)*N } & 3 & 0.45 & 3.20 & 0.0262 & 3 & 0.03 & 1.03 & 0.3835 & 3 & 0.04 & 1.78 & 0.1549 \\ \text { Site(Region)*P*N } & 3 & 0.13 & 0.93 & 0.4304 & 3 & 0.09 & 3.38 & 0.0211 & 3 & 0.01 & 0.50 & 0.6856 \\ \text { Residual } & 108 & 0.14 & & & & 108 & 0.03 & & & 108 & 0.02 & \end{array}$


Figure Captions:

Fig. 1: Map of Florida Bay and study sites. Bay regions are defined based on delineations from Zieman et al. (1989). Region A: Gulf/Atlantic, Region B: Interior/East Central, Region C:

Northeast.

Fig. 2: Responses of sediment nutrient content to region and $\mathrm{P}$ and $\mathrm{N}$ addition: a) $\mathrm{P}$ content as a percent of dry weight, b) $\mathrm{N}$ content as a percent of dry weight. At site A1, $\mathrm{n}=3$ per nutrient treatment; at all other sites, $\mathrm{n}=6$. In all figures, significant $\mathrm{p}$-values are indicated and all bars represent standard error.

Fig. 3: Responses of Thalassia testudinum nutrient content to region and $\mathrm{P}$ and $\mathrm{N}$ addition: a) $\mathrm{P}$ content as a percent of dry weight, b) $\mathrm{N}$ content as a percent of dry weight, c) N:P molar ratio. At site $A 1, n=3$ per nutrient treatment; at all other sites, $n=6$.

Fig. 4: Responses of Thalassia testudinum epiphyte nutrient content to region and $\mathrm{P}$ and $\mathrm{N}$ addition: a) P content as a percent of dry weight, b) $\mathrm{N}$ content as a percent of dry weight, c) N:P molar ratio. $n=6$ per site per nutrient treatment. $\Psi$ indicates insufficient replication for analysis. Fig. 5: Responses of primary producers to region and $\mathrm{P}$ and $\mathrm{N}$ addition: a) Thalassia testudinum percent cover, estimated by Braun-Blanquet (BB) score, b) $\underline{\text { T. testudinum }}$ short-shoot (ss) productivity, c) uncalcified red algae (Rhodophyta) cover, d) calcified green algae (Chlorophyta) cover, e) epiphyte chlorophyll $a$ concentration, f) benthic chlorophyll $a$ concentration. At site A1, $n=3$ per site per nutrient treatment; at all other sites, $n=6 . \Psi$ indicates insufficient replication for analysis. $\S$ indicates no macroalgae present. 
Armitage et al.

Figure 1

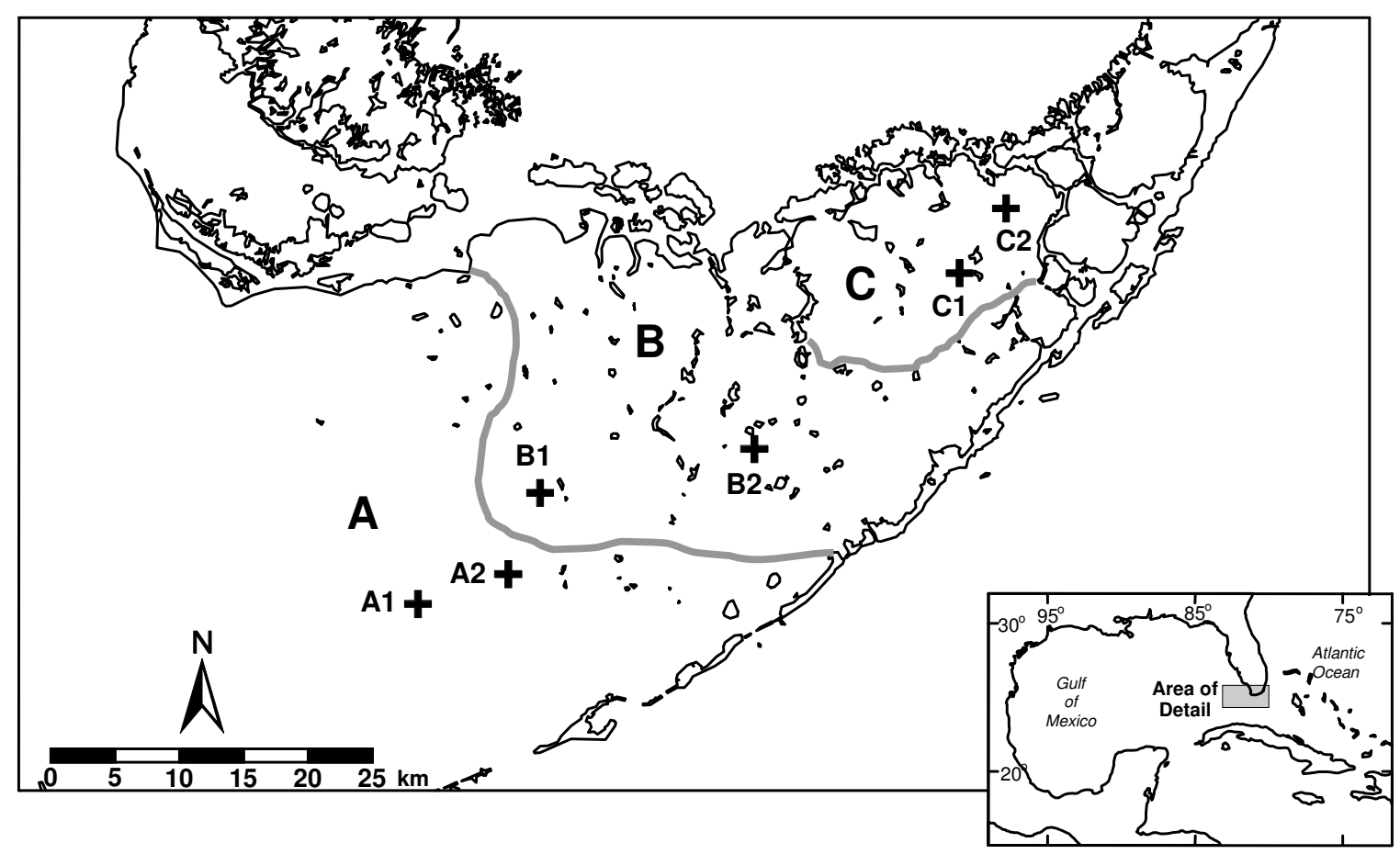


Figure 2
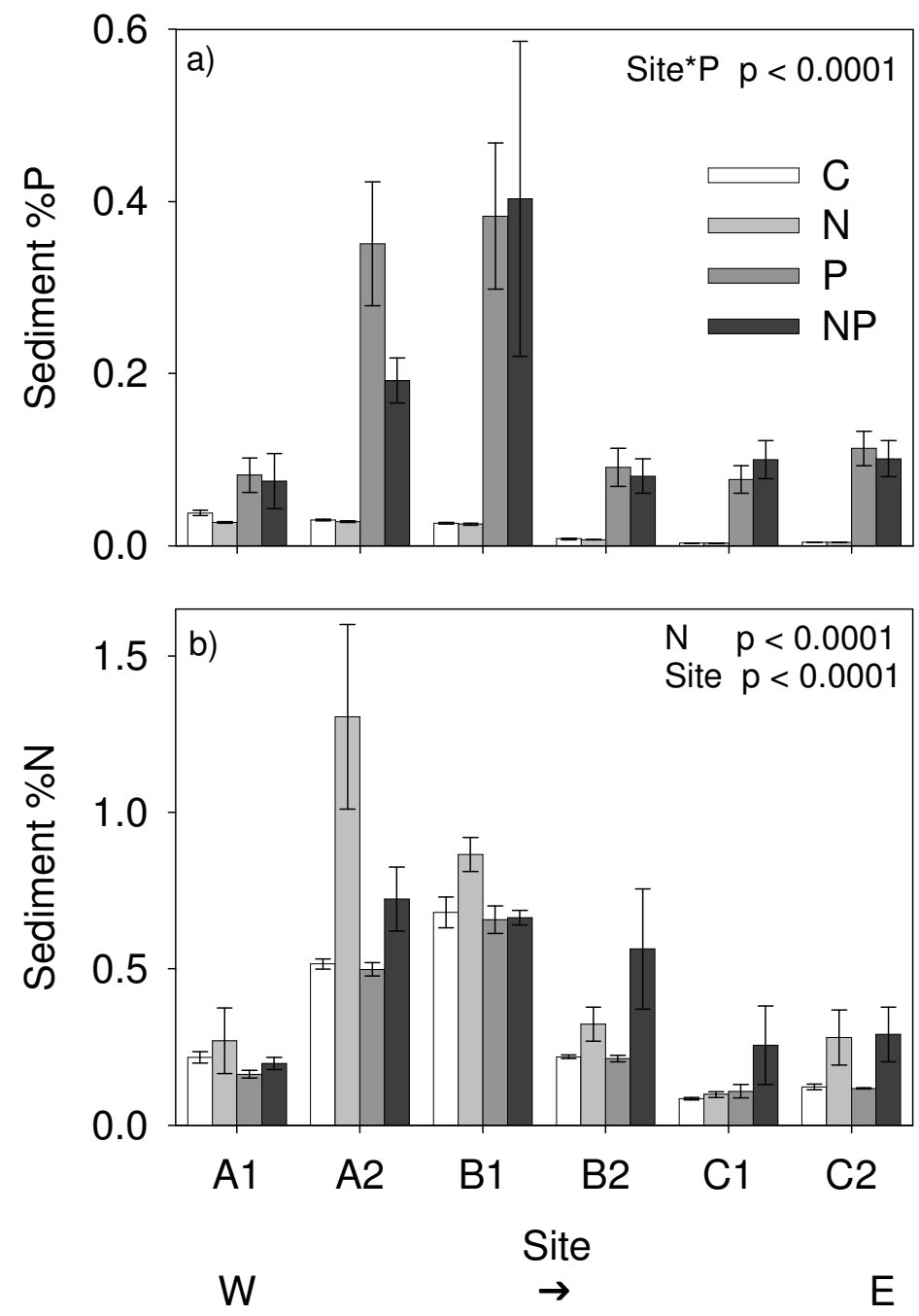
Armitage et al.

Figure 3
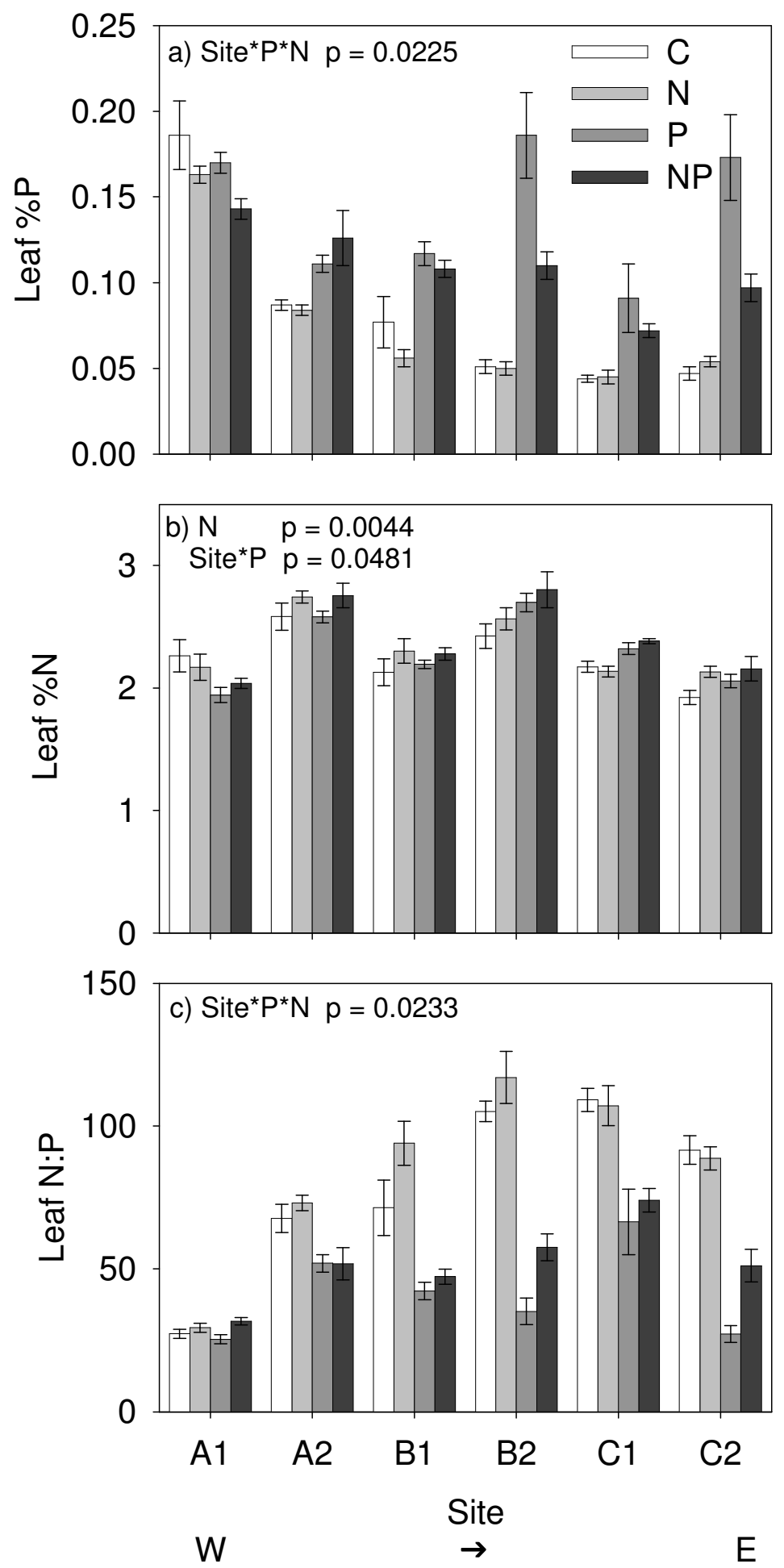
Armitage et al.

Figure 4
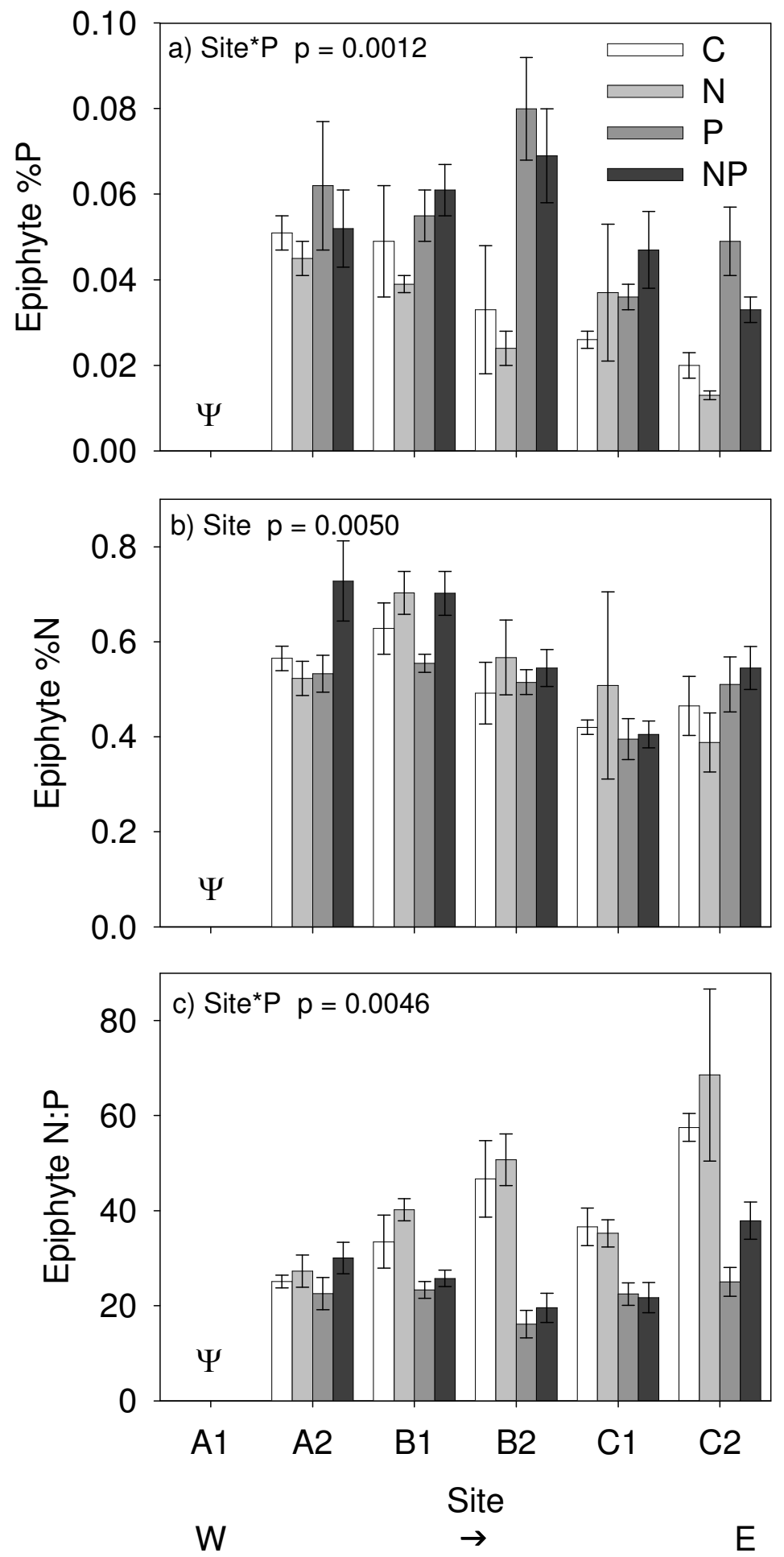
Armitage et al.

40

Figure 5
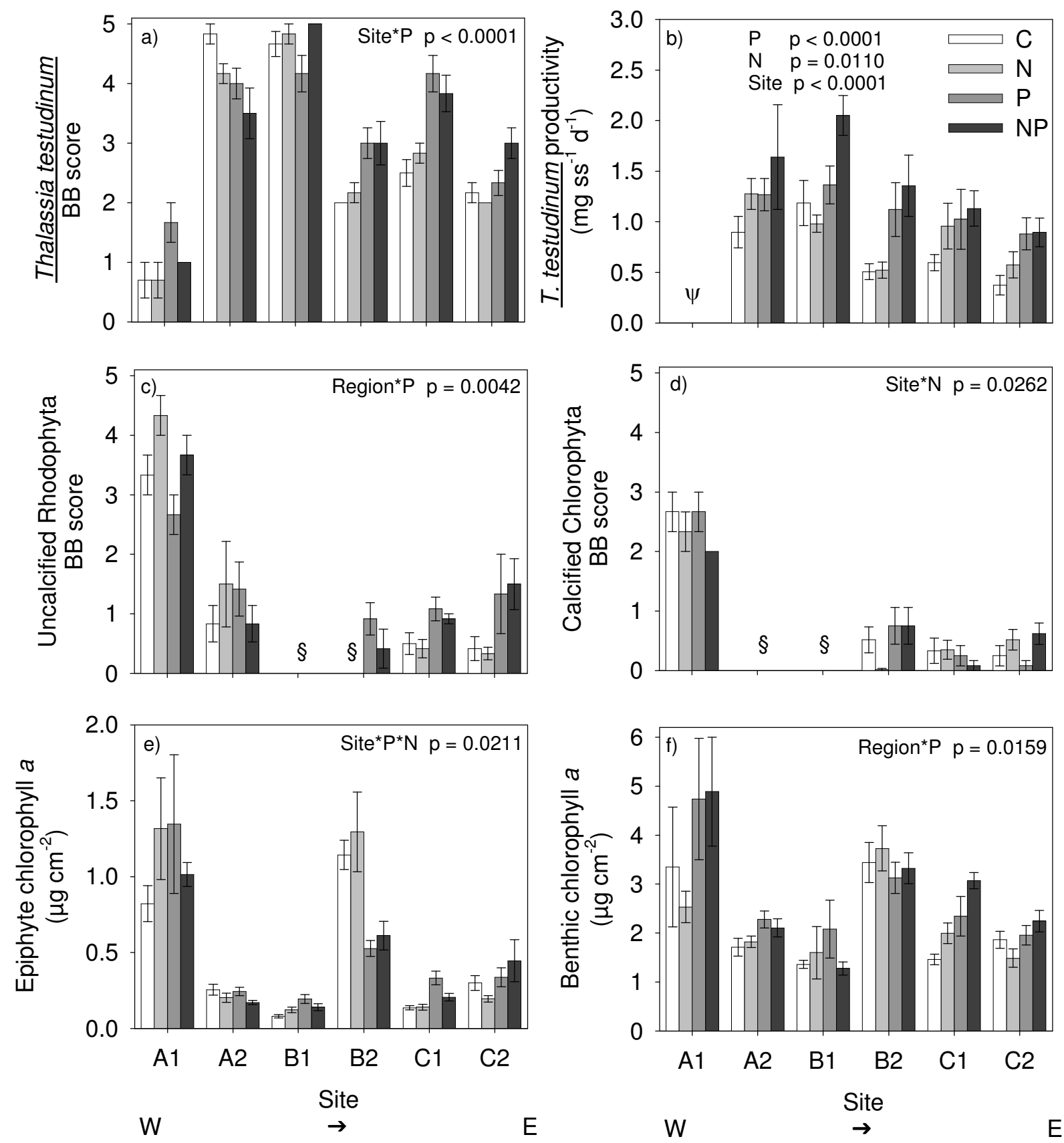